\title{
THE ECONOMIC VALUE OF ECOSYSTEM SERVICES OF RUBBER-BASED AGROFOREST PLANTATIONS IN SOUTH THAILAND
}

\author{
NARUN NATTHAROM ${ }^{1 *}$, SAOWALAK ROONGTAWANREONGSRI ${ }^{1}$ AND SARA \\ BUMRUNGSRI $^{2}$
}

${ }^{1}$ Faculty of Environmental Management, Prince of Songkla University, 15 Karnjanavanich Rd., Hat Yai, Songkhla, 90110 Thailand. ${ }^{2}$ Department of Biology, Faculty of Science, Prince of Songkla University, 15 Karnjanavanich Rd., Hat Yai, Songkhla 90110 Thailand.

*Corresponding author: narun.psu@gmail.com

Submitted final draft: 28 August $2020 \quad$ Accepted: 5 September $2020 \quad$ http://doi.org/10.46754/jssm.2021.07.016

\begin{abstract}
The objective of this study was to estimate the ecosystem service values of three types of rubber-based agroforest plantations and monoculture rubber plantations in the southern region of Thailand, covering a life cycle of 25 years. Three ecosystem services were investigated in this study: timber production, $\mathrm{CO}_{2}$ sequestration, and $\mathrm{O}_{2}$ production. The study used data collected from 29 plantations and used growth prediction models from previous research to determine the quantity and value of the ecosystem services. The results showed that at at the $25^{\text {th }}$ year, the agroforest rubber plantation that cultivated Hevea brasiliensis Mull-Arg. with Hopea odorata Roxb., Shorea roxburghii G.Don. and Swietenia macrophylla King. provided the highest value of timber production, $\mathrm{CO}_{2}$ sequestration and $\mathrm{O}_{2}$ production (190622.62 USD/ha, 5918.5 USD/ha and 90779.3 USD/ha, respectively), whereas the monoculture rubber plantation provided the lowest value (11715.12 USD/ ha, 565.8 USD/ha and 6587.5 USD/ha, respectively). Overall, the agroforest plantations provided higher benefit than monoculture plantations. The findings can be used to support farmers and governmental agencies to diversify monoculture rubber plantations, which will ultimately contribute to environmental and human well-being.
\end{abstract}

Keywords: Rubber-based, agroforestry, economic value, environmental services, sustainable agriculture.

Abbreviations: Diameter at breast height (DBH), total height $(\mathrm{TH})$, merchantable height (MH).

\section{Introduction}

Rubber (Hevea brasiliensis Mull-Arg.) plantations are a source of natural rubber, a versatile material that is important to humans for daily life (Ngolemasango et al., 2008; Palosuo et al., 1998; Shibata et al., 2007). There is a constant demand for natural rubber globally: 12.27 million tonnes in 2014, which increased to 13.91 million tonnes in 2019, an average increment of 0.33 million tonnes/ year (Office of Agricultural Economics, 2020). This demand is continuously driving the expansion of commercial monoculture rubber plantation areas. In 2014, the total area of rubber plantations worldwide was 12.41 million ha, increasing to 14.17 million ha in 2019 , an growth rate of $0.41 \mathrm{ha} /$ year on average (Office of Agricultural Economics, 2020). The increase of monoculture rubber plantations is a major cause of tropical forest area reduction (Keenan et al., 2015; Warren-Thomas et al., 2020). The loss of forest areas decreases essential ecosystem services, such as oxygen production, carbon sequestration (Foley et al., 2007; Martínez et al., 2009), soil erosion control (Nuanmano, 2013; Wittahawatchutikul, 1993), soil nutrient cycling (Bumrungsri et al., 2011; Waiyarat, 2016) and biodiversity (Beukema et al., 2007; Bumrungsri et al., 2011; Ayat \& Tata, 2015).

The modification of monoculture rubber plantations to rubber-based agroforestry plantations can be an alternative approach in lessening the loss of ecosystem services (van Noordwijk et al., 2012). There have been studies showing that the ecosystem services of rubberbased agroforestry plantations are superior to 
monoculture rubber plantations. For instance, because agroforestry plantations contain a variety of species and number of trees, they increase the potential for carbon sequestration (Bumrungsri et al., 2011; Kumar \& Nair, 2011), habitats (Bumrungsri et al., 2011; Ayat \& Tata, 2015; Warren-Thomas et al., 2020), and food sources for various animal species (Bumrungsri et al., 2011; Warren-Thomas et al., 2020). In addition, the large number of trees in the agroforests increases the litterfall volume (Bumrungsri et al., 2011; Waiyarat, 2016). The complexity of the canopy maintains air temperature and humidity (Yunis et al., 1990; Brooks \& KykerSnowman, 2008), which can accelerate the decomposition of organic matter (Golley, 1983; Swift \& Anderson, 1989), resulting in a high decomposition rate. Therefore, the soil has fertile nutrients, which help the plants grow better. The study of ecosystem services of agroforestry plantations are legitimate. However, research on the monetary value of such ecosystem services is quite scarce. Most of the literature aforementioned usually studied the physical quantity of ecosystem services in a particular year, but did not cover the monetary value of ecosystem services or the whole cycle of a rubber plantation. For example, Bumrungsri et al. (2011) studied the carbon storage of a 45-year rubber agroforest plantation, as well as 15-year and 17-year monoculture rubber plantations in Phatthalung province, southern Thailand. Bridhikitti (2017) studied a 20-year rubber plantation in Buriram province, northeast Thailand. In addition, we found studies that focused on the quantity, but not the monetary value of the ecosystem services throughout the lifecycle of rubber plantations, such as a study by Chiarawipa et al. (2009), who looked into the timber volume of monoculture rubber plantations in replanting area of the Office of Rubber Replanting Aid Fund in Songkhla province, southern Thailand, as well as another study by Chiarawipa et al. (2012) on carbon storage of monoculture rubber plantations in Songkhla province, southern Thailand. Only Roongtawanreongsri et al. (2015) studied $\mathrm{CO}_{2}$ sequestration and $\mathrm{O}_{2}$ production alongside monetary value in 25-year rubber plantations on Kho Hong Hill, Songkhla province, southern Thailand. The monetary value is often recognised by rubber farmers as an incentive to change from monoculture farms to an agroforestry one.

This research was aimed at estimating the economic value of ecosystem services in terms of timber production, $\mathrm{CO}_{2}$ sequestration, and $\mathrm{O}_{2}$ production in both systems of monoculture and rubber-based agroforest plantations in southern Thailand. Timber production value is an important benefit that rubber farmers receive directly and can be considered as a private benefit. The values of $\mathrm{CO}_{2}$ sequestration and production of $\mathrm{O}_{2}$, on the other hand, are environmental and social benefits that involve the wider communities. The estimation covers the whole 25-year lifecycle of rubber plantations of both systems. The agroforest plantations in this study refer to the practice of planting rubber with intercropping economic trees that are promoted by the government and can grow under the canopy of rubber (Booranatam et al., 2003; Department of Agriculture, 2016), including Hopea odorata Roxb. (takhian thong), Shorea roxburghii G.Don. (payom), Swietenia macrophylla King. (mahogany), Dipterocarpus alatus Roxb. (yang-na), and Azadirachta excelsa (Jack) Jacobs. (sadao-thiam). The results of the study can guide farmers and government agencies on the decision to choose or support rubber-based agroforest plantations, which will ultimately contribute to human and ecosystem well-being

\section{Materials and Methods}

\section{The Study Area}

Twenty-nine small-scale rubber plantations in this study were located in Trang, Phatthalung and Songkhla provinces, Southern Thailand ( $5^{\circ} 57^{\prime}$ to $10^{\circ} 59^{\prime} \mathrm{N}$ and $98^{\circ} 11^{\prime}$ to $102^{\circ} 04^{\prime}$ E) (Figure 1). All these plantations were under similar influences of elevations and rainfall, which are elevations of below 100 , with an annual average rainfall of between $1,600 \mathrm{~mm}$ and 2,400 mm (Climatological Centre, 2020). 

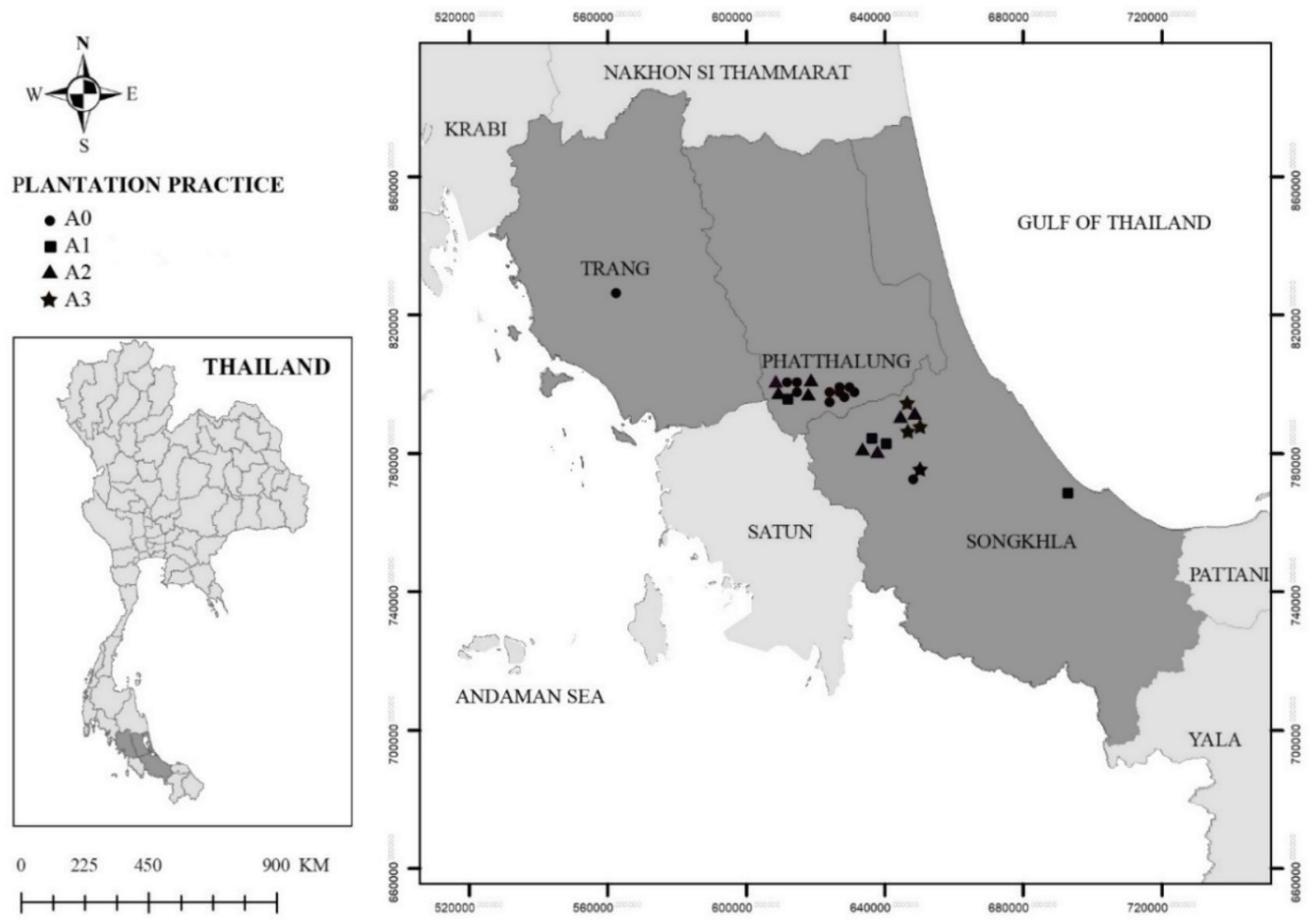

Figure 1: Locations of the study sites

\section{The Plantation Types}

From the survey and interviews, there were three different common types of rubber-based agroforests in southern Thailand: rubber with two other species (H. odorata and $S$. roxburghii), or A1; rubber with three other species (H. odorata, $S$. roxburghii, and $S$. macrophylla), or A2; and, rubber with five other species (H. odorata, $S$. roxburghii, S. macrophylla, D. alatus, and $A$. excelsa), or A3 (Table 1). We also included the monoculture type (A0) as a comparison. Farmers often plant rubber trees in a row, with a distance of $3 \mathrm{~m}$ between each tree, and a distance of 7 $\mathrm{m}$ between each row, as recommended by the Rubber Research Institute of Thailand (2018). With this pattern, 475 rubber trees would cover an area of $1 \mathrm{ha}$. The intercropping trees were planted in between the rows of rubber, with a distance of $3.5 \mathrm{~m}$ between the rows. The total number of intercropping trees was about half of the total number of rubber trees, which is 237 tree ha $^{-1}$ (Figure 2). Usually, farmers grow economic forest trees after planting rubber for three years to offset the disadvantage of $H$. brasiliensis competing with the intercropping trees. From our interviews, rubber-based agroforests were not widely practised in southern Thailand, and the number of plantations was limited as the majority of rubber farmers cultivate monoculture rubber plantations instead. However, among farmers who planted intercropping trees, A2 was the most common.

\section{Growth Prediction}

Tree growth parameters that are necessary for valuating ecosystem services, such as timber production, $\mathrm{CO}_{2}$ sequestration, and $\mathrm{O}_{2}$ production, are the trees' diameter at breast height $(\mathrm{DBH})$, total height $(\mathrm{TH})$, and merchantable height $(\mathrm{MH})$ at the particular age that the value would accrue. DBH is the diameter of the bole of a standing tree at $1.30 \mathrm{~m}$, while TH 
Table 1: The plantation type and the number of tree species of each type

\begin{tabular}{lclccc}
\hline \multicolumn{2}{c}{ Plantation type } & \multicolumn{1}{c}{ Species } & $\begin{array}{c}\text { Number of trees } \\
\text { (tree/ha) }\end{array}$ & $\begin{array}{c}\text { Total number of } \\
\text { trees (trees/ha) }\end{array}$ & $\begin{array}{c}\text { Number of } \\
\text { plantation }\end{array}$ \\
\hline Monoculture & A0 & H. brasiliensis & 475 & 475 & 13 \\
Agroforestry & A1 & H. brasiliensis & 475 & & \\
& & H. odorata & 118 & 711 & \\
& & S. roxburghii & 118 & & \\
& A2 & H. brasiliensis & 475 & & \\
& & H. odorata & 79 & 712 & \\
& & S. roxburghii & 79 & & \\
& S. macrophylla & 79 & & \\
& A. brasiliensis & 475 & & \\
& H. odorata & 47 & & \\
& S. roxburghii & 47 & & \\
& S. macrophylla & 47 & & \\
& D. alatus & 47 & & \\
& A. excelsa & 47 & & \\
\hline
\end{tabular}

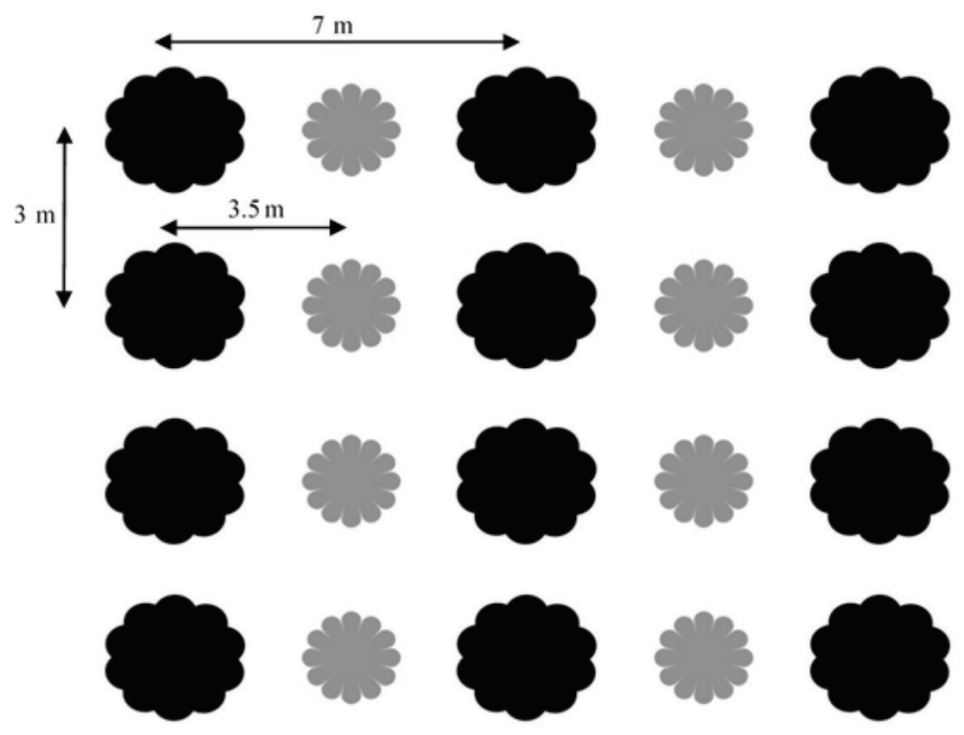

Figure 2: The planting pattern of $H$. brasiliensis and intercropping trees

is the perpendicular distance between the axis of the bole of the tree from the ground to the uppermost point, and $\mathrm{MH}$ is the distance from the base of the tree to the first branching or other defects of the tree (Brack, 1999). Our previous work, in the same study area as in this study (Nattharom et al., 2020), has generated growth models from a regression analysis, which used $\mathrm{DBH}, \mathrm{TH}$, and $\mathrm{MH}$ data from 14 monoculture rubber plantations and 25 rubber-based agroforest plantations in Trang, Phatthalung, and Songkhla provinces. Six species were found on those farms. The main species was H. brasiliensis, which was separated into two 
groups: the trees before tapping (1-7 years) (140 trees) and the trees after tapping ( $>7$ years) (725 trees). For intercropped trees, there were H. odorata (521 trees), S. roxburghii (368 trees), S. macrophylla (243 trees), D. alatus (194 trees) and A. excelsa (131 trees) (Table 2). This study continues from the previous work by calculating the amount of timber, $\mathrm{CO}_{2}$, and $\mathrm{O}_{2}$, based on the growth prediction models. Also, the interviews with the farmers were employed to gain more insights into their practice on agroforests.

Table 2: Predictive models for tree growth parameters

\begin{tabular}{|c|c|}
\hline Tree Species & Model \\
\hline \multirow{3}{*}{$\begin{array}{l}\text { H. brasiliensis } \\
\text { (before tapping) }\end{array}$} & $\mathrm{DBH}=2.095 \mathrm{x}^{1.060}$ \\
\hline & $\mathrm{TH}=3.337 \mathrm{x}^{0.655}$ \\
\hline & $\mathrm{MH}=2.387 \mathrm{e}^{0.167 \mathrm{x}}$ \\
\hline \multirow{3}{*}{$\begin{array}{l}\text { H. brasiliensis } \\
\text { (after tapping) }\end{array}$} & $\mathrm{DBH}=5.845 \mathrm{x}^{0.467}$ \\
\hline & $\mathrm{TH}=3.850 \mathrm{x}^{0.468}$ \\
\hline & $\mathrm{MH}=5.276 \mathrm{e}^{0.020 \mathrm{x}}$ \\
\hline \multirow{3}{*}{ H. odorata } & $\mathrm{DBH}=2.748 \mathrm{e}^{0.108 x}$ \\
\hline & $\mathrm{TH}=2.777 \mathrm{e}^{0.086 \mathrm{x}}$ \\
\hline & $\mathrm{MH}=1.575 \mathrm{e}^{0.099 \mathrm{x}}$ \\
\hline \multirow{3}{*}{ S. roxburghii } & $\mathrm{DBH}=1.160 \mathrm{x}^{1.030}$ \\
\hline & $\mathrm{TH}=3.580 \mathrm{e}^{0.067 \mathrm{x}}$ \\
\hline & $\mathrm{MH}=2.190 \mathrm{e}^{0.078 \mathrm{x}}$ \\
\hline \multirow{3}{*}{ S. macrophylla } & $\mathrm{DBH}=3.248 \mathrm{e}^{0.130 x}$ \\
\hline & $\mathrm{TH}=4.281 \mathrm{e}^{0.084 \mathrm{x}}$ \\
\hline & $\mathrm{MH}=2.859 \mathrm{e}^{0.094 \mathrm{x}}$ \\
\hline \multirow{3}{*}{ D. alatus } & $\mathrm{DBH}=2.746 \mathrm{e}^{0.072 x}$ \\
\hline & $\mathrm{TH}=2.752 \mathrm{e}^{0.067 \mathrm{x}}$ \\
\hline & $\mathrm{MH}=1.801 \mathrm{e}^{0.070 \mathrm{x}}$ \\
\hline \multirow{3}{*}{ A. excelsa } & DBH $=\mathrm{e}^{3.733-6.227 / \mathrm{x}}$ \\
\hline & $\mathrm{TH}=\mathrm{e}^{3.253-4.147 / \mathrm{x}}$ \\
\hline & $\mathrm{MH}=\mathrm{e}^{2.978-4.204 / \mathrm{x}}$ \\
\hline
\end{tabular}

Source: Nattharom et al. (2020)

\section{Valuation of Timber Provisioning Service}

Timber value is the value of rubber trees and economic forest trees grown in a plantation.

The value of timber is the main benefit that would be the incentive for farmers to be interested in rubber-based agroforest plantations, because it is an actual income that accrues directly to the farmers out of selling timber in the market. Considering the current low price of rubber latex, the timber value is, therefore, an excellent alternative source of income.

Timber can be accounted for as commercial sales when its DBH is larger than $15.4 \mathrm{~cm} \mathrm{(6}$ in). This size is the minimum size that is traded for logs of rubber trees (Rubber Authority of Thailand, 2019) and economic forest trees (Malaysian Timber Industry Board, 2019). Generally, economic forest trees are traded in volume units $\left(\mathrm{m}^{3}\right)$, whereas rubber trees are traded in weight units $(\mathrm{kg})$. The timber volume of forest trees is determined by the following equation (1) by Magnussen (2004):

$\mathrm{V}=0.42 \times \mathrm{BA} \times \mathrm{MH}$

Where $\mathrm{V}$ is the timber volume $\left(\mathrm{m}^{3}\right), 0.42$ is the coefficient of a tree stem's shape, BA is a tree's basal area at breast height $(\mathrm{m})$, and $\mathrm{MH}$ is a tree's merchantable height $(\mathrm{m})$.

Rubber timber was determined by the following equation (2) by Sangsing et al. (2007):

$\mathrm{W}=1009.8 \mathrm{~V}+2.6028$

Where $\mathrm{W}$ is the timber weight $(\mathrm{kg})$, and $\mathrm{V}$ is the timber volume $\left(\mathrm{m}^{3}\right)$.

The timber volume was then multiplied by its market price to determine the revenue. $S$. roxburghii, $A$. excelsa, and $S$. macrophylla timber prices were obtained from the local markets (490. 8, 351.3, and $351.4 \mathrm{USD} / \mathrm{m}^{3}$ respectively). The prices of $H$. odorata (545.4 $\left.\mathrm{USD} / \mathrm{m}^{3}\right)$ and $D$. alatus $\left(292.9 \mathrm{USD} / \mathrm{m}^{3}\right)$ were quoted from the log import prices of the Royal Forest Department (2016). The price of rubber trees $(0.06 \mathrm{USD} / \mathrm{kg})$ was obtained from the rubberwood factory in Southern Thailand (Rubber Authority of Thailand, 2019).

The net value of timber was calculated by deducting the cost of logging from the revenue. The logging costs of economic forest trees were obtained from Roongtawanreongsri et al. 
(2007), and the rubber tree from the Rubber Authority of Thailand (2017).

The timber provisioning service occurs only once a year when the timbers are logged. The timbers are logged when the DBH is larger than $15.4 \mathrm{~cm}$ (Malaysian Timber Industry Board, 2019; Rubber Authority of Thailand, 2019), or in the case of this study, from the 8th year onwards. Once the timbers are logged, they will no longer produce the service until the new plants have grown to the desired size. However, we calculated the value of the timber every year to provide information to relevant stakeholders that are considering cutting the timber in a particular year.

\section{Valuation of $\mathrm{CO}_{2}$ Sequestration and $\mathrm{O}_{2}$ Production Services}

Although there is currently no market system that supports the trading of $\mathrm{CO}_{2}$ and $\mathrm{O}_{2}$ from rubber plantations for farmers directly, $\mathrm{CO}_{2}$ sequestration and $\mathrm{O}_{2}$ production services are considered a social benefit. Particularly, $\mathrm{CO}_{2}$ sequestration helps mitigate the environmental problem of greenhouse gases. Therefore, the value of these services is crucial for government agencies that oversee environmental policies.

Unlike the service of timber, which occurs only once a year when the wood is cut, the benefit of the ecosystem services of $\mathrm{CO}_{2}$ sequestration and $\mathrm{O}_{2}$ production occurs every year as long as the trees stand intact. The annual quantities of $\mathrm{CO}_{2}$ sequestration and $\mathrm{O}_{2}$ production were calculated from the tree biomass, which is derived using the following equation (3), which is the sum of aboveground biomass and belowground biomass:

$$
\mathrm{B}=\mathrm{W}_{\mathrm{t}}+\mathrm{W}_{\mathrm{r}}
$$

Where $\mathrm{B}$ is the tree biomass $(\mathrm{kg}), \mathrm{W}_{\mathrm{t}}$ is the aboveground biomass $(\mathrm{kg})$, and $\mathrm{W}_{\mathrm{r}}$ is the belowground biomass $(\mathrm{kg})$.

The aboveground biomass was calculated following the allometric regression equations for tropical rainforests and dry evergreen forests in Thailand by Tsutsumi et al. (1983):

$$
\begin{gathered}
\mathrm{W}_{\mathrm{s}}=0.0509\left(\mathrm{DBH}^{2} \times \mathrm{TH}\right)^{0.919} \\
\mathrm{~W}_{\mathrm{b}}=0.00893\left(\mathrm{DBH}^{2} \times \mathrm{TH}\right)^{0.977} \\
\mathrm{~W}_{1}=0.0140\left(\mathrm{DBH}^{2} \times \mathrm{TH}\right)^{0.669} \\
\mathrm{~W}_{\mathrm{t}}=\mathrm{W}_{\mathrm{s}}+\mathrm{W}_{\mathrm{b}}+\mathrm{W}_{1}
\end{gathered}
$$

Where DBH is the diameter at breast height, $\mathrm{TH}$ is the total height, $\mathrm{W}_{\mathrm{s}}$ is the stem biomass $(\mathrm{kg})$, $\mathrm{W}_{\mathrm{b}}$ is the branch biomass $(\mathrm{kg})$ and $\mathrm{W}_{1}$ is the leaf biomass (kg).

As seen in the equations, the tree's DBH and $\mathrm{TH}$ data in a particular year are needed. These growth sizes are difficult to measure annually, so they are predicted using the growth models generated specifically for these exact species, which were done in a previous research (Nattharom et al., 2020).

The belowground biomass was calculated using the root-to-shoot ratio in the tropical latitudinal zone by Cairns et al. (1997):

$$
\mathrm{W}_{\mathrm{r}}=\mathrm{W}_{\mathrm{t}} \times 0.24
$$

Where $\mathrm{W}_{\mathrm{r}}$ is the belowground biomass $(\mathrm{kg}), \mathrm{W}_{\mathrm{t}}$ is the aboveground biomass $(\mathrm{kg})$, and 0.24 is the root-to-shoot ratio in the tropical zone (Cairns et al., 1997).

The amount of annual $\mathrm{CO}_{2}$ sequestration and $\mathrm{O}_{2}$ production was estimated using the following equation (6). The annual biomass increments from the first year to the $25^{\text {th }}$ of each species were first determined:

$$
\mathrm{BI}=\mathrm{B}_{\mathrm{t}+1}-\mathrm{B}_{\mathrm{t}}
$$

Where $\mathrm{BI}$ is the biomass increment $(\mathrm{kg}), \mathrm{B}$ is the tree biomass $(\mathrm{kg})$, and $\mathrm{t}$ is the time (year).

Then the amount of carbon was estimated by multiplying the annual biomass increment by the carbon conversion factor for trees in the tropical zone (Eggleston et al., 2006). The $\mathrm{CO}_{2}$ sequestration amount was finally calculated by multiplying the estimated amount of carbon by the carbon dioxide conversion factor (Meepol, 2010):

$$
\mathrm{C}=(\mathrm{BI} \times 0.47) \times 3.67
$$

Where $\mathrm{C}$ is the $\mathrm{CO}_{2}$ sequestration $\left(\mathrm{kgCO}_{2}\right)$, $\mathrm{BI}$ is the biomass increment $(\mathrm{kg}), 0.47$ is the carbon 
conversion factor (Eggleston et al., 2006) and 3.67 is the carbon dioxide conversion factor (Meepol, 2010).

A similar procedure was applied to the calculation of the amount of $\mathrm{O}_{2}$ production, only that the annual tree biomass increment was multiplied directly by the oxygen conversion factor (Yolasiğmaz \& Keleş, 2009):

$$
\mathrm{O}=\mathrm{BI} \times 1.2
$$

where $\mathrm{O}$ is the $\mathrm{O}_{2}$ production $\left(\mathrm{kgO}_{2}\right), \mathrm{BI}$ is the biomass increment $(\mathrm{kg})$, and 1.2 is oxygen conversion factor (Yolasiğmaz \& Keleş, 2009).

Therefore, since there was no biomass increment in the first year, it was treated as no ecosystem services were provided. After the second year and throughout the life of the plantation, the services were continuously provided each year.

The annual value of $\mathrm{CO}_{2}$ sequestration was calculated by multiplying the annual quantity of $\mathrm{CO}_{2}$ sequestration by the price of $\mathrm{CO}_{2}$, in which the $\mathrm{CO}_{2}$ European Emission Allowances price (Insider incorporated \& Finanzen.net $\mathrm{GmbH}$, 2020 on February 21, 2020, was assumed, which was $28.1 \mathrm{USD} / \mathrm{tCO}_{2 \mathrm{eq}}$.

Since the price of $\mathrm{O}_{2}$ production in nature is not directly market-observed, the value of this service was calculated based on the concept of cost-based pricing. The cost-based methods (damage cost avoided, replacement cost, and substitute cost methods) are related methods that estimate the values of ecosystem goods and services based on either the costs of avoiding damages due to lost services, the cost of replacing environmental assets, or the cost of providing substitute goods or services. The substitute cost method, in particular, uses the cost of providing substitutes for an ecosystem or its goods and services as an estimate of the value of the ecosystem or its goods and services (Forest Ecosystem and Biodiversity Programme Officer (Plan Bleu), 2015). This method has been used in prior works, for example, $\mathrm{Wu}, \mathrm{Hou}$, \& Yuan (2010), Xi (2009), and Carey \& Tobin (2016). They calculated oxygen production services of either trees or forests using the cost of industrial oxygen production.

Thus, the $\mathrm{O}_{2}$ production value in this study was calculated by multiplying the annual quantity of $\mathrm{O}_{2}$ production by the local market price of industrial oxygen supply, which was $470 \mathrm{USD} / \mathrm{tO}_{2}$ (Sathing Phra Hospital, 2020; Somdejprabororomrachineenart Natawee Hospital, 2020).

Note that all prices were adjusted to the current price (2020) using the consumer index (Ministry of Commerce, 2020). The exchange rate was based on the average value on March 27, 2020, which was $1 \mathrm{USD}=32.4$ baht and 1 USD $=1.1$ ERU (Bank of Thailand, 2020).

\section{Results and Discussion}

The value of timber production, $\mathrm{CO}_{2}$ sequestration, $\mathrm{O}_{2}$ production and total ecosystem services at each tree's age is shown in Table 3.

\section{Timber Provisioning Service}

The monoculture rubber plantations, A0, provided the lowest volume and value of timber $\left(94.1 \mathrm{~m}^{3} / \mathrm{ha}\right.$ and $4562 \mathrm{USD} / \mathrm{ha}$ at 25 years), while plantations with rubber trees and three other forest tree species, A2, provided the highest volume of timber provisioning service $\left(340.1 \mathrm{~m}^{3} / \mathrm{ha}\right.$ and $39,325 \mathrm{USD} / \mathrm{ha}$ at 25 years). This result was not unexpected since monoculture plantations contain only rubber trees; thus, the volume of timber must naturally be lower than those that contain rubber trees and other economic forest trees. Among the different types of agroforests, A2 provided the largest service, followed by $\mathrm{A} 3$, or plantations with rubber trees and five other forest tree species, and $\mathrm{A} 1$, or plantations with rubber trees and two other tree species.

\section{$\mathrm{CO}_{2}$ Sequestration and $\mathrm{O}_{2}$ Production Services}

The results of these two ecosystem services, which were calculated from the annual biomass increment, show that all types of plantations provided increased quantities and values of 


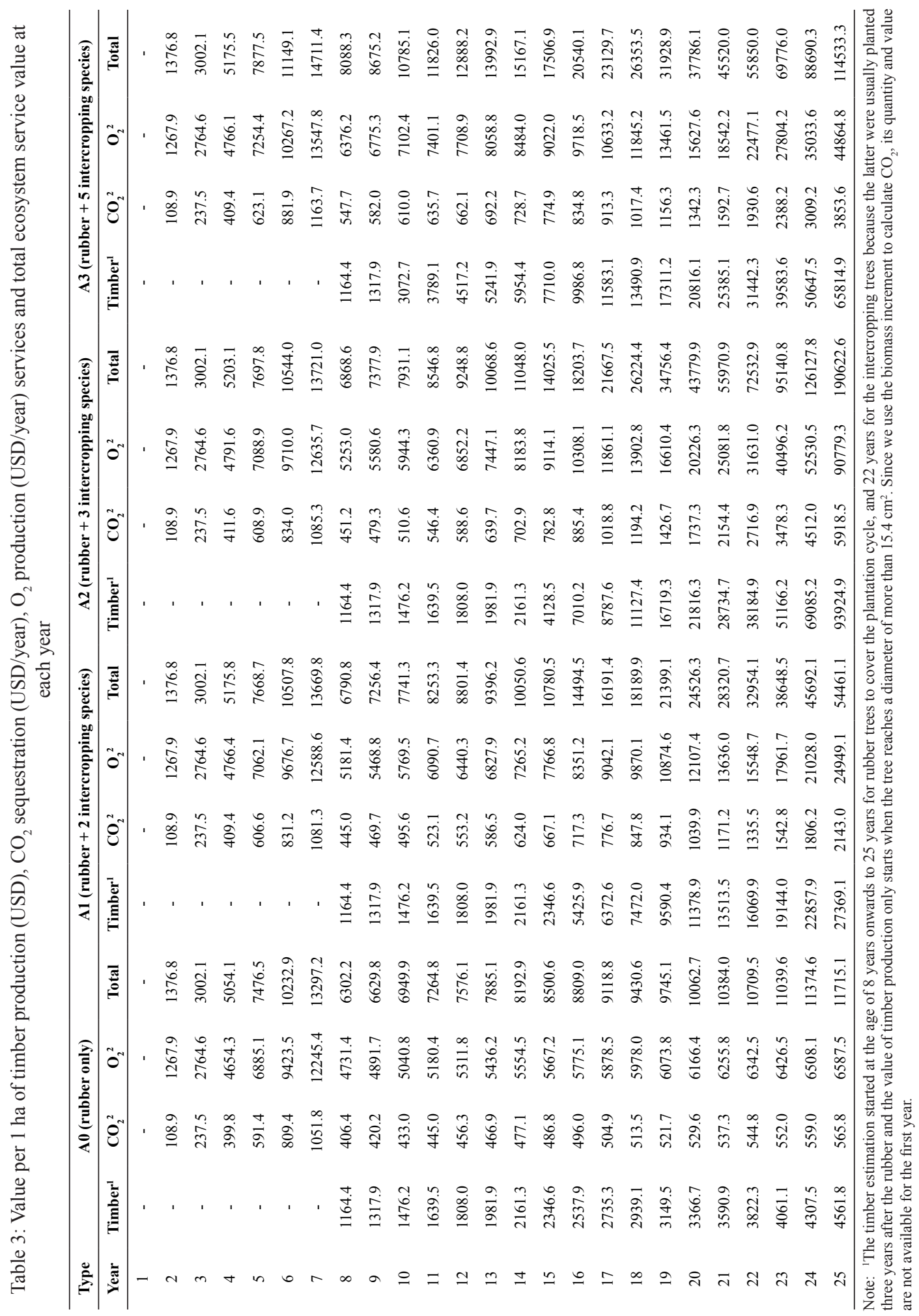


$\mathrm{CO}_{2}$ sequestration and $\mathrm{O}_{2}$ production services each year. Note that there was a drop in the quantity at year 8 due to the predictive growth models. According to Nattharom et al. (2020), the models for predicting rubber growth were separated into two phases: rubber before tapping (1-6 years old) and rubber after tapping ( 7 years old up), as generally, the rubber trees grow faster when they have not been tapped. Hence, in each type, the services dropped at the age of 8 years old and started to increase again from that point onwards. In general, A2 plantations provided the largest quantities and values of $\mathrm{CO}_{2}$ sequestration and $\mathrm{O}_{2}$ production services, whereas A0 plantations, again, provided the lowest services.

This study determined the quantities and values of timber production, $\mathrm{CO}_{2}$ sequestration, and $\mathrm{O}_{2}$ production services of one monoculture and three common rubber-based agroforest plantation types in southern Thailand with the aid of growth prediction from a previous study. The results show that although monoculture rubber plantations (A0) showed the potential of fixing $\mathrm{CO}_{2}$ from the atmosphere into the stem (Bridhikitti, 2017; Chiarawipa et al., 2012; Jusheng \& Rusong, 2002) and release $\mathrm{O}_{2}$ into the atmosphere (Jusheng \& Rusong, 2002), the total value of all three ecosystem services was not as high as the remaining agroforest types. The main reason is due to the fact that monoculture rubber plantations contain only rubber trees, so the number of trees is less than the other types of plantations (A0 contains 475 trees/ha, A1 711 trees/ha, A2 712 trees/ha, and A3 710 tree/ha). Additionally, the price of rubberwood compared with the wood of other economic trees is extremely low as rubberwood is considered an agricultural by-product and its logs are not high quality (Balsiger et al., 2000).

All types of rubber-based agroforest plantations provided a higher total ecosystem service value than monoculture plantations. This is because the agroforests contain not only the rubber trees, but as many as 237 intercropping trees as well. Intercropping was an important reason for the difference in ecosystem services between monoculture and agroforest plantations.
With the calculation based on growth parameters like $\mathrm{DBH}, \mathrm{TH}$, and $\mathrm{MH}$, it was natural that the ecosystem services would depend on the growth pattern of the tree species. Thus, among the agroforest types, the ecosystem services varied due to the different growth rates of the economic forest tree species. For instance, A2 provided the highest ecosystem service value as a result of intercropping with $S$. macrophylla, which had a higher biomass increment than the other species in the study (Table 4).

Table 4: The average annual biomass increments of each species in this study

\begin{tabular}{cc}
\hline Tree species & $\begin{array}{c}\text { Average increment } \\
\text { biomass (kg) }\end{array}$ \\
\hline H. brasiliensis & 21.94 \\
H. odorata & 59.65 \\
S. roxburghii & 25.23 \\
S. macrophylla & 323.92 \\
D. alatus & 7.10 \\
A. excelsa & 36.23 \\
\hline
\end{tabular}

The average annual biomass increment of S. macrophylla, which we calculated from the predictive model by Nattharom et al. (2020), was considerably high when compared with other tree species in this study. Unfortunately, due to the limitation of the number of research on the annual size and the biomass of $S$. macrophylla that covers a period of 22 years, the accuracy of the prediction could not be verified. However, we found that $S$. macrophylla is classified as a tree in the fast-growing group (Forestry Research Center, 2009) and the growth rate of $S$. macrophylla increased according to annual precipitation (Shono \& Snook, 2006). In Songkhla, Phattalung and Trang provinces, the annual precipitation is $1,600-2,400 \mathrm{~mm}$ (Climatological Centre, 2020), which is very high compared with other areas that studied the size of S. macrophylla: northwestern Belize, Mexico had an annual precipitation of $1600 \mathrm{~mm}$ (Shono \& Snook, 2006) southeast Para'state, Brazil $1859 \mathrm{~mm}$ (Grogan et al., 2010) and Quintana Roo, Mexico $1300 \mathrm{~mm}$ (Roo et al., 2014). 
The high increment in biomass showed that $S$. macrophylla could sequester the largest amount of $\mathrm{CO}_{2}$ and produced the largest quantity of $\mathrm{O}_{2}$ compared with other species of the same age. Since the amount of biomass is related to the tree size (Sheil et al., 2017), the timber production of the larger-size species would provide a high volume of timber, too. Therefore, in this study, the number of $S$. macrophylla trees was an important variable influencing the ecosystem services of the agroforest plantations.

Comparisons of the results with other researches in Thailand needs to consider similar tree species, tree density, and environmental conditions because they can affect the provision of the ecosystem services (Panuthai et al., 2012). However, the study on the ecosystem services of agroforestry in Thailand is still lacking, let alone the value of ecosystem services in the same region. Therefore, Table 5 shows only the comparison of the quantity of ecosystem services of monoculture rubber plantations. The comparison with the study by Chiarawipa et al. (2009) showed that timber production service in this study was lower. This difference may be the result of different methods of timber estimation. Chiarawipa et al. (2009) studied the timber volume in the replanting area of the Office of Rubber Replanting Aid Fund in
Songkhla province, southern Thailand, by using two equations to estimate timber volume in logs and timber as a standing volume before using them to generate the relationship between a tree's age and timber volume. On the contrary, in this study, we used the tree size data from growth prediction models that was estimated by the curvilinear regression to calculate the timber volume.

The volume of the $\mathrm{CO}_{2}$ sequestration service in this study was similar to that of Roongtawanreongsri et al. (2015). We did not find other research in the same region that provides the amount of $\mathrm{CO}_{2}$ sequestration, so we compared the results to the research of $\mathrm{C}$ storage in Thailand, including the study on the 20 -year rubber plantation in Buriram province, northeast Thailand (Bridhikitti, 2017), and the 25-year rubber plantation in Songkhla province, southern Thailand (Chiarawipa et al., 2012). Since these studies presented the figures in $\mathrm{C}$ storage volume, the conversion to $\mathrm{CO}_{2}$ was done using a conversion factor, which was 3.67 (Meepol, 2010). The figures showed that the results of this study were not much different from those of the other studies. We could not locate any other literature on $\mathrm{O}_{2}$ production, except that of Roongtawanreongsri et al. (2015). The comparison shows that the estimation of

Table 5: Comparison of ecosystem services of monoculture rubber plantations between other studies and this research

\begin{tabular}{|c|c|c|c|}
\hline Ecosystem service & $\begin{array}{c}\text { Quantity of other } \\
\text { studies }\end{array}$ & Reference & $\begin{array}{l}\text { Quantity of this } \\
\text { study }\end{array}$ \\
\hline Timber production & $145.92 \mathrm{~m}^{3} / \mathrm{ha}$ & Chiarawipa et al. (2009) & $94.1 \mathrm{~m}^{3} / \mathrm{ha}$ \\
\hline $\begin{array}{l}\mathrm{CO}_{2} \text { sequestration in } \\
\text { 25-year-old rubber } \\
\text { plantation }\end{array}$ & $24.07 \mathrm{t} \mathrm{CO}_{2} /$ ha/year & $\begin{array}{l}\text { Roongtawanreongsri et al. } \\
\qquad(2015)\end{array}$ & $20.1 \mathrm{t} \mathrm{CO}_{2} /$ ha/year \\
\hline $\begin{array}{l}\mathrm{C} \text { storage in } 20 \text {-year-old } \\
\text { rubber plantation }\end{array}$ & $62.6 \mathrm{tC} / \mathrm{ha}$ & Bridhikitti (2017) & $68.47 \mathrm{tC} / \mathrm{ha}$ \\
\hline $\begin{array}{l}\mathrm{C} \text { storage in } 25 \text {-year-old } \\
\text { rubber plantation }\end{array}$ & $139.65 \mathrm{tC} / \mathrm{ha}$ & Chiarawipa et al. (2012) & $104.93 \mathrm{tC} / \mathrm{ha}$ \\
\hline $\begin{array}{l}\mathrm{O}_{2} \text { production in in } \\
25 \text {-year-old rubber } \\
\text { plantation }\end{array}$ & $13.39 \mathrm{tO}_{2} / \mathrm{ha}$ & $\begin{array}{l}\text { Roongtawanreongsri et al. } \\
\qquad(2015)\end{array}$ & $14 \mathrm{tO}_{2} / \mathrm{ha}$ \\
\hline
\end{tabular}

${ }^{1}$ The Quantity of $\mathrm{CO}_{2}$ sequestration was calculated from $\mathrm{C}$ storage multiplied by the $\mathrm{CO}_{2}$ conversion factor of 3.67 (Meepol, 2010). 
$\mathrm{O}_{2}$ production in this study was close to the mentioned research.

In terms of the value of the ecosystem services, it was more challenging to find research that studied the value of the ecosystem service of agroforest plantations in the same region. We found the study by Ployninpet (2012), who estimated the timber value of the secondary forest on Kho Hong Hill, Songkhla province, at 10637.7 USD/ha. We also found the study by Roongtawanreongsri et al. (2015), which estimated the value of the ecosystem services of the same forest. Their study derived the value of $\mathrm{CO}_{2}$ and $\mathrm{O}_{2}$ at $1754 \mathrm{USD} / \mathrm{ha} /$ year and $18382 \mathrm{USD} / \mathrm{ha} / \mathrm{year}$, respectively. Note that all values were adjusted to current values using the consumer index price.

It is plausible to note that using the valuation technique of the substitute cost method to represent the value of $\mathrm{O}_{2}$ production may be overestimated, according to the Forest Ecosystem and Biodiversity Programme Officer (Plan Bleu) (2015). However, not quantifying its value may overlook its significance as forests play the leading role in oxygen production, which is around $54 \%$ in relation to all terrestrial vegetation (Lakyda, 2011). Furthermore, the oxygen content of the atmosphere is slowly declining due to fossil fuel combustion from human activities (Nowak, Hoehn, \& Crane, 2007). Therefore, the value of $\mathrm{O}_{2}$ production in this study can be used primarily to note the importance of this service provided by agroforests, but it should not be appropriately considered a direct benefit. It must be interpreted with caution until more studies with precise measurements of value can be done.

The comparison showed that all ecosystem service values of secondary forests were higher than monoculture rubber plantations, but lower than all types of agroforest rubber plantations. The fact that secondary forests provided a lower value of ecosystem services than agroforest rubber plantations was considered possible. This phenomenon was also seen in the study of an Acacia mangium Willd. plantation in Chachoengsao province, eastern Thailand.
The plantation had a $\mathrm{CO}_{2}$ sequestration rate of $56.36 \mathrm{tCO}_{2} /$ ha/year, which was substantially higher than that of the mixed deciduous forest in Kanchanaburi province, eastern Thailand, which was $17.75 \mathrm{tCO}_{2} /$ ha/year (Panuthai et al., 2012), so their growths are higher, resulting in the use of more $\mathrm{CO}_{2}$ and production of more $\mathrm{O}_{2}$. This issue thus leaves room for further research on planting patterns or some other innovations to increase or facilitate better growth.

At present, there is a proposed concept for farmers to modify the current rubber planting system, which is from the single-row planting pattern $(3 \times 7 \mathrm{~m})$, or the traditional planting system, to a double-row planting pattern $(4 \mathrm{~m}$ with a $20 \mathrm{~m}$ gap between double rows) (Xianhai, 2012; Chiarawipa, 2019) to increase the space for intercropping. Double-row planting can reduce the resource competition between the rubber trees and intercropping trees, which results in better intercropping growth and yield (Chiarawipa, 2019; Rubber Authority of Thailand, 2018; Xianhai, 2012). However, the increase of the distance and the number of intercropping would need to be traded off with the number of rubber trees, and thus the amount of natural rubber production (Rubber Authority of Thailand, 2018; Chiarawipa, 2019). Therefore, further study on double-row planting is needed to provide insights for farmers and the relevant authorities.

The contribution of this study may partly guide the future promotion of agroforestry in Thailand. Currently, even though they deliver more environmental services and require less input (Gouyon et al., 1993; Kittitornkool et al., 2014), rubber-based agroforests are not widespread as national policies have continuously promoted monoculture plantations (Somboonsuke et al., 2010; Kheowvongsri \& Pechkeo, 2017). From our interviews with farmers, in addition, most of them believe that monoculture plantations yield higher latex compared with rubber-based agroforests. However, according to Kittitornkool et al. (2014) and Warren-Thomas et al. (2020), there were no significant difference in latex yield between rubber-based agroforestry and monoculture 
rubber plantations. Thus the concern is clearly the result of farmers' lack of precise information on the cost-benefit comparison between the two systems. Additionally, some farmers express concerns over difficulties in moving around the farm and the fear of poisonous animals in the agroforests due to its high biodiversity. Knowledge transfer from agroforest farmers to monoculture farmers may further enhance the learning and alleviate non-substantial concerns on farm management practices. Future studies that include economic and environmental benefits throughout the rubber plantation lifecycle should be carried out to provide insights so that better decisions can be made.

The explicit limitation of this study is that it has not included other ecosystem services, such as soil protection, microclimate controlling, biodiversity, or habitats for various species. Although A2 plantations appear to provide the highest ecosystem service value, even higher than secondary forests, they still do not have varied plant species. The diversity of trees influences multiple ecosystem services (Gamfeldt et al., 2013). Tree diversity in rubber agroforest plantations affect the complexity of the canopy (Kittitornkool et al., 2014), which helps maintain the air temperature (Yunis et al., 1990; Brooks \& Kyker-Snowman, 2008) unheated greenhouses in Israel during the winter of $1987 / 88$. The winter was characterized by a relatively large number of rainy days. The relative humidity (RH and soil moisture (Islam et al., 2016; Özkan \& Gökbulak, 2017)minimum, and mean daily temperatures. In addition, having a variety of tree species increases habitat and food sources for various animal species (Bumrungsri et al., 2011; Warren-Thomas et al., 2020). It is inevitable that the estimated values in this study are thus underestimated.

\section{Conclusion}

This study shows that all types of agroforest rubber plantations in the lower southern region of Thailand can provide higher value of timber provision, $\mathrm{CO}_{2}$ sequestration, and $\mathrm{O}_{2}$ production services than monoculture rubber plantations.
The value of ecosystem services can motivate farmers to modify or diversify monoculture rubber plantations to become agroforest rubber plantations. By doing so, farmers can secure not only their private income, but also the social benefit for the wider communities.

The application of this study depends on the purpose and intention of the management. For example, in terms of encouraging monoculture farmers to diversify their crop plants to improve the ecosystem services as well as higher economic benefits, A2 plantations should be recommended. However, A3 plantations, which have the most variety of tree species, should be recommended to increase habitats for animal species and other ecosystem services that have not been studied. The results cannot, by any means, be interpreted that agroforest plantations should replace the natural forests. Future studies should include other ecosystem services for a complete understanding of various types of agroforestry compared with natural forests. Also, it should include ecosystem services that are important in terms of environmental issues, such as biodiversity, soil erosion control, and water cycle control. These services may encourage monoculture rubber farmers to switch to agroforestry. Consequently, it may lead to the development of payment for ecosystem service projects that will increase the benefits for farmers who maintain the ecosystem and the general public, who are users of ecological services. However, for the time being, the results of this study can fill the gaps of the research on three ecosystem services, both in terms of quantity and economic value, of four rubber plantation types. It can immediately be used to guide the improvement of monoculture rubber plantations and the decision to promote the rubber-based agroforest plantations that provides direct benefits to farmers, as well as environmental benefits that can alleviate the problems of forest ecosystem loss.

\section{Acknowledgements}

This research was partly supported by the National Research Council of Thailand. The 
authors gratefully appreciate the help of 29 rubber farmers who allowed researchers to collect data from their farms and researchers from the Environmental Economic Research Unit, Prince of Songkla University, who supported the data collection process.

\section{References}

Ayat, A., \& L. Tata, H. (2015). Diversity of birds across land use and habitat gradients in forests, rubber agroforests and rubber plantations of North Sumatra. Indonesian Journal of Forestry Research, 2(2), 103-120. https://doi. org/10.20886/ijfr.2015.2.2.829.103-120

Balsiger, J., Bahdon, J., \& Whiteman, A. (2000). The utilisation, processing and demand for rubberwood as a source of wood supply. http:// www.fao.org/3/a-y0153e.pdf

Bank of Thailand. (2020). Exchange rate. https:// www.bot.or.th/thai/_layouts/application/ exchangerate/exchangerate.aspx (Thai)

Beukema, H., Danielsen, F., Vincent, G., Hardiwinoto, S., \& Van Andel, J. (2007). Plant and bird diversity in rubber agroforests in the lowlands of Sumatra, Indonesia. Agroforestry Systems, 70(30), 217-242. https://doi.org/10.1007/ s10457-007-9037-x

Booranatam, W., Jantama, A., Jantama, P., Pachana, P., Bamrungwong, P., Petying, P., Somnak, S., \& Boonmorakot, P. (2003). Planting some economic forest trees as intercroppin in rubber plantation. Rubber Research Institute of Thailand, Department of Agriculture. (Thai)

Brack, C. (1999). Merchantable height of a single tree. https://fennerschool-associated.anu.edu.au/ mensuration/merchhgt.htm

Bridhikitti, A. (2017). Soil and biomass carbon stocks in forest and agricultural lands in tropical climates. Songklanakarin Journal of Science and Technology, 39(6), 697-707. https://doi. org/10.14456/sjst-psu.2017.85

Brooks, R. T., \& Kyker-Snowman, T. D. (2008). Forest floor temperature and relative humidity following timber harvesting in southern New England, USA. Forest Ecology and Management, 254(1), 65-73. https://doi. org/10.1016/j.foreco.2007.07.028
Bumrungsri, S., Sawangchote, P., Tapedontree, J., Nattharom, N., Bauloi, K., Chatchai, N., \& Billasoy, S. (2011). Litter fall and decomposition rate, density of earthworm, carbon storage, diversity of birds and bats in rubber agroforestry and monoculture rubber plantation at Thamod District, Phatthalung Provice. Department of Biology, Faculty of Science, Prince of Songkla University. (Thai)

Cairns, M. A., Brown, S., Helmer, E. H., \& Baumgardner, G. A. (1997). Root biomass allocation in the world's upland forests. Oecologia, 111(2), 1-11 https://doi.org/10.1007/ s004420050201

Carey, B., \& Tobin, B. (2016). Ecosystem services provided by Mountshannon Village Trees. Current Biology. https:// www.itreetools.org/documents/332/ Mountshannon i Tree Report Final_25Sept2016.pdf?fbclid=IwAR30nU1 m4MXUNn4bZCrwJBUGafyRk0JYkxdPknmN49LSbMQOZ7zEfovTNc

Chiarawipa, R., Pechkeo, S., Keawdoung, M., \& Prommee, W. (2012). Assessment of Carbon Stock and the Potential Income of the Carbon Offset in Rubber Plantation. Burapha Science Journal, 17(2), 91-102. (Thai)

Chiarawipa, R., Yeedum, I., \& Sdoodee, S. (2009). Assessment of wood volume and latex yield in the Office of Rubber Replanting Aid Fund's Replanting area: The-pha district, Songkhla Province. Thai Science and Technology Journal, 17(1), 66-77. (Thai)

Chiarawipa, R. (2019). Rubber-based Intercropping System in Southern Thailand: Its constraints and planting patterns on sustainable productivity. King Mongkut's Agricultural Journal, 37(1), 179-189.

Climatological Center. (2020). Thirty years climate statistics. http://climate.tmd.go.th/statistic/ stat30y (Thai)

Department of Agruculture. (2016). Alternatives of intercropping and income generating activities of rubber farmers. http://www.doa.go.th/share /attachment.php?aid=1193 (Thai)

Eggleston, S., Bendia, L., Miwa, K., Ngara, T., \& Tanabe, K. (2006). 2006 IPCC guidelines for national greenhouse gas inventories. https://doi. org/10.1007/978-3-642-41714-6_62425 
Forest Ecosystem and Biodiversity Programme Officer (Plan Bleu). (2015). Sustainable Forest Management: Socio-economic assessment of goods and services provided by Mediterranean forest ecosystems. https://planbleu.org/sites/ default/files/publications/forest_factsheets_ methods.pdf

Forestry Research Center. (2009). Project of tree plantation promotion for long-term saving. Faculty of Forestry, Kasetsart University, Bangkok, Thailand. (Thai)

Foley, J. A., Asner, G. P., Costa, M. H., Coe, M. T., DeFries, R., Gibbs, H. K., Howard, E. A., Olson, S., Patz, J., Ramankutty, N., \& Snyder, P. (2007). Amazonia revealed: Forest degradation and loss of ecosystem goods and services in the Amazon Basin. Frontiers in Ecology and the Environment, 5(1), 25-32. https://doi.org/10.1890/15409295(2007)5[25:ARFDAL]2.0.CO;2

Gamfeldt, L., Snäll, T., Bagchi, R., Jonsson, M., Gustafsson, L., Kjellander, P., Ruiz-Jaen, M. C., Fröberg, M., Stendahl, J., Philipson, C. D., Mikusiński, G., Andersson, E., Westerlund, B., Andrén, H., Moberg, F., Moen, J., \& Bengtsson, J. (2013). Higher levels of multiple ecosystem services are found in forests with more tree species. Nature Communications, 4(1), 1-8. https://doi.org/10.1038/ncomms2328

Golley, F. (1983). Nutrient cycling and nutrient conservation. In F. Golley (Eds.), Tropical Rain Forest ecosystems (pp.137-156). Elsevier.

Gouyon, A., de Foresta, H., \& Levang, P. (1993). Does "jungle rubber" deserve its name? An analysis of rubber agroforestry systems in southeast Sumatra. Agroforestry Systems, 22(3), 181-206. https://doi.org/10.1007/BF00705233

Grogan, J., Schulze, M., \& Galvão, J. (2010). Survival, growth and reproduction by big-leaf mahogany (Swietenia macrophylla) in open clearing vs. forested conditions in Brazil. New Forests, 40(3), 335-347. https://doi.org/10.1007/ s11056-010-9203-2

Insider incorporated, \& Finanzen.net GmbH. (2020). $\mathrm{CO}_{2}$ European emission allowances in USD historical prices. https://markets.businessinsider. com/commodities/historical-prices/co2european-emission-allowances/euro/3.1.2020 3.4.2020? fbclid=iwar2ah28gzcoc25ivztllpf4fZ-va3ayiplzbenmbr8s98ocxujtj4teq 4
Islam, M., Salim, S. H., Kawsar, M. H., \& Rahman, M. (2016). The effect of soil moisture content and forest canopy openness on the regeneration of Dipterocarpus turbinatus C.F. Gaertn. (Dipterocarpaceae) in a protected forest area of Bangladesh. Tropical Ecology, 57(3), 455-464. https://doi.org/10.1101/gad.310304

Jusheng, J., \& Rusong, W. (2002). Function of carbon sequestration and oxygen release of rubber plantations and its value estimation. Acta Ecologica Sinica, 22(9), 1545-1551.

Keenan, R. J., Reams, G. A., Achard, F., de Freitas, J. V., Grainger, A., \& Lindquist, E. (2015). Dynamics of global forest area: Results from the FAO global forest resources assessment 2015. Forest Ecology and Management, 352, 9-20. https://doi.org/10.1016/j.foreco.2015.06.014

Kheowvongsri, P., \& Pechkeo, S. (2017). Rubber agroforest. http:/hsmi2.psu.ac.th/upload/forum/ project_423_5d7912d0006105d791.pdf(Thai)

Kittitornkool, J., Bumrungsri, S., Kheowvongsri, P., Tongkam, P., Waiyarat, R., Nattharom, N., \& Uttamunee, W. (2014). A Comparative study of integrated dimensions of sustainability between agroforest and monoculture rubber plantations. Prince of Songkla University. https:/www. biodconference.org/wp-content/uploads /2017/03/12.-page-073-078.pdf (Thai)

Kumar, B. M., \& Nair, P. K. R. (2011). Carbon sequestration potential of agroforestry systems: opportunities and challenges. Springer Science \& Business Media.

Lakyda, I. (2011) Carbon-sequestering and oxygenproducingfunctions of urban forests of Kyiv city andpre-urban forests of Stockholm city. (Master's thesis, Forest Management, Swedish University of Agricultural Sciences, Uppsala, Sweden). Retrieved from https://pdfs.semanticscholar.org/fb42/ e 7c7fda 8041765 b632c3d127748bf5e6d436. pdf_ga=2.230825439.139365570.1598495840733568403.1598495840

Malaysian Timber Industry Board. (2019). Timber prices. http:/www.mtib.gov.my/ componentcontent/article/2-uncategorised/87timber-prices

Martínez, M. L., Pérez-Maqueo, O., Vázquez, G., Castillo-Campos, G., García-Franco, J., Mehltreter, K., Equihua, M., \& Landgrave, 
R. (2009). Effects of land use change on biodiversity and ecosystem services in tropical montane cloud forests of Mexico. Forest Ecology and Management, 258(9), 1856-1863. https://doi.org/10.1016/j.foreco. 2009.02 .023

Meepol, W. (2010). Carbon sequestration of mangrove forests at ranong biosphere reserve. Journal of Forest Management, 4(7), 33-47. (Thai)

Ministry of Commerce. (2020). Table of consumer price index http://www.indexpr.moc.go.th/ price_present/cpi/stat/others/indexg_report2.asp (Thai)

Nattharom, N., Roongtawanreongsri, S., \& Bumrungsri, S. (2020). Growth prediction for rubber tree and intercropped forest trees to facilitate environmental services valuation in South Thailand. Biodiversitas, 21(5), 2019-2034. https://doi.org/10.13057/ biodiv/d210528

Ngolemasango, F. E., Bennett, M., \& Clarke, J. (2008). Degradation and life prediction of a natural rubber engine mount compound. Journal of Applied Polymer Science, 110(1), 348-355. https://doi.org/10.1002/app.28424

Nowak, D. J., Hoehn, R., \& Crane, D. E. (2007). Oxygen production by urban trees in the United States. Arboriculture and Urban Forestry, 33(3), 220-226.

Nuanmano, N. (2013). Soil erosion on Kho Hong Hill and its economic loss, Hat Yai District, Songkhla Province (Master's thesis, Faculty of Environmental Management, Prince of Songkla University, Songkhla, Thailand). Retrieved from http://kb.psu.ac.th /psukb/handle/2010/9027 (Thai)

Office of Agricultural Economics. (2020). Important trends of agricultural products in B.E.2563. http://www.oae.go.th/assets/portals/1/files/ trend2563-Final-Download.pdf (Thai).

Özkan, U., \& Gökbulak, F. (2017). Effect of vegetation change from forest to herbaceous vegetation cover on soil moisture and temperature regimes and soil water chemistry. Catena, 149, 158-166. https://doi.org/10.1016/j.catena.2016.09.017

Palosuo, T., Mäkinen-Kiljunen, S., Alenius, H., Reunala, T., Yip, E., \& Turjanmaa, K. (1998). Measurement of natural rubber latex allergen levels in medical gloves by allergen-specific
IgE-ELISA inhibition, RAST inhibition, and skin prick test. Allergy, 53(1), 59-67. https://doi. org/10.1111/j.1398-9995.1998.tb03774.x

Panuthai, S., Janmahasathien, S., Viriyabuncha, C., Latpala, P., Visaratana, T., Diloksumpun, S., \& Marod, D. (2012). Potential of conserved forest and economic forest for carbon sequestration. http://frc.forest. ku.ac.th/frcdatabase/bulletin/ws_document /R015201.pdf (Thai)

Ployninpet, N. (2012). Economic valuation of timber, poles, sapling abd seedling on kho Hong Hill, Hat Yai District, Songkhla Province (Master's thesis, Faculty of Environmental Management, Prince of Songkla University, Songkhla, Thailand). Retrieved from http://kb.psu.ac.th/ psukb/handle/2010/8800 (Thai)

Roo, Q., Negreros-castillo, P., \& Mize, C. W. (2014). Mahogany growth and mortality and the Relation of Growth to Site Characteristics in a Natural Forest in Quintana Roo, Mexico, 60(5), 907-913.

Roongtawanreongsri, S., Darnsawasdi, R., \& Gampoo, P. (2007). Economic valuation of timber from Khao Hua Chang, Tamot SubDistrict, Tamot District, Patthalung Province. Thammasat Economic Journal, 25(1). (Thai)

Roongtawanreongsri, S., Sawangchote, P., Bumrungsri, S., \& Suksaroj, C. (2015). Economic benefit of management options for a suburban forest (Kho Hong Hill) in South Thailand. In D. James \& H. A. Francisco (Eds.), Costbenefit studies of natural resource management in Southeast Asia (pp. 275-298). Singapore: Springer. https://doi.org/10.1007/978-981-287393-4

Royal Forest Department. (2016). Prices of imported logs and sawn timber B.E. 2559. http://forestinfo. forest.go.th/Content/file/stat2559/Table 22.pdf (Thai)

Rubber Authority of Thailand. (2017). Calculation to estimate the price of rubber wood in the rubber plantations before felling. https://km.raot.co.th/ kmknowledge/detail/222 (Thai)

Rubber Authority of Thailand. (2018). Rubber information B.E. 2561. 2018. http://online. pubhtm15.com/lfcj/oubi/\#p=2 (Thai)

Rubber Authority of Thailand. (2019). Summary of purchase-sale prices of rubber wood B.E. 2562. https://km.raot.co.th/uploads/dip/userfiles/ 
intra_ฝายวิจัยและพัฒนาเศรษฐกิจยาง/ 11111 . pdf (Thai)

Rubber Research Institute of Thailand. (2018). Information of para rubber. http://online. pubhtml5.com/lfcj/oubi/\#p=7 (Thai)

Sangsing, K., Paechana, P., \& Chaiphanit, P. (2007). Survey and estimation of rubber wood for commerce before felling. Para Rubber Bulletin, 28(2), 50-70. (Thai)

Sathing Phra Hospital. (2020). Report of approval for medical supplies payment B.E. 2563. Songkhla, Thailand. (Thai)

Sheil, D., Eastaugh, C. S., Vlam, M., Zuidema, P. A., Groenendijk, P., van der Sleen, P., Jay, A., \& Vanclay, J. (2017). Does biomass growth increase in the largest trees? Flaws, fallacies and alternative analyses. Functional Ecology, 31(3), 568-581. https://doi.org/10.1111/13652435.12775

Shibata, S., Ochi, K., Aono, Y., Noguchi, H., \& Oshima, H. (2007). Fatigue characteristics of vulcanised natural rubber for automotive engine mounting. Key Engineering Materials, 67(2), 75-83. https://doi.org/10.4028/www.scientific. net/kem.353-358.178

Shono, K., \& Snook, L. K. (2006). Growth of big-leaf mahogany (Swietenia macrophylla) in natural forests in Belize. Journal of Tropical Forest Science, 18(1), 66-73.

Somboonsuke, B., Wetprasit, P., Niyombandith, T., Kaesaman, A., \& Tekasakul, P. (2013) Solution to the low rubber prices problem. http:/www.pbwatch.net/Events/Rubber/NR_ Seminar_20130903_01.pdf(Thai)

Somdejprabororomrachineenart Natawee Hospital. (2020). Report of approval for medical supplies payment B.E. 2563. Songkhla, Thailand. (Thai)

Swift, M. J., \& Anderson, J. (1989). Decomposition. In H. Lieth \& M. J. A. Werger (Eds.) Tropical rand forest ecosystems (pp.547-569). Elsevier.

Tsutsumi, T., Yoda, K., Dhanmanonda, P., \& Prachaiyo, B. (1983). Forest: Felling, burning and regeneration. In K. Kyuma \& C. Pairintra (Eds.), Shifting cultivation: An experiment at Nam Phrom, northeast Thailand and its implications for upland farming in the monsoon tropics (pp. 13-62). Kyoto University, K.

van Noordwijk, M., Tata, H. L., Xu, J., Dewi, S., \& Minang, P. A. (2012). Segregate or integrate for multifunctionality and sustained change through rubber-based agroforestry in Indonesia and China. In P. Nair \& D. Garrity (Eds.), Agroforestry-the future of global land use (pp. 69-104). Netherlands: Springer. https://doi. org/10.1007/978-94-007-4676-3_8

Waiyarat, R. (2016). Litter fall and rubber leaf decomposition in rubber agroforest and monoculture rubber plantation in Southern Thailand (Master's thesis, Department of Biology, Faculty of Science, Prince of Songkla University, Songkhla, Thailand). http://kb.psu. ac.th/psukb/bitstream/2016/11461/1/418293.pdf

Warren-Thomas, E., Nelson, L., Juthong, W., Bumrungsri, S., Brattström, O., Stroesser, L., Chambon, B., Penot, É., Tongkaemkaew, U., Edwards, D. P., \& Dolman, P. M. (2020). Rubber agroforestry in Thailand provides some biodiversity benefits without reducing yields. Journal of Applied Ecology, 57(1), 17-30. https://doi.org/10.1111/1365-2664.13530

Wittahawatchutikul, P. (1993). Agroforestry concept at Rayong province. Thai Journal of Forest, 12, 159-167. (Thai)

Wu, S., Hou, Y., \& Yuan, G. (2010). Valuation of forest ecosystem goods and services and forest natural capital of the Beijing municipality, China. http:// www.fao.org/3/i1507e/i1507e07.pdf

$\mathrm{Xi}$, J. (2009). Valuation of ecosystem services in Xishuangbanna biodiversity conservation corridors initiative pilot site, China. http:// www.gms-eoc.org/uploads/resources/72/ attachment/Valuation of Ecosystem Services in Xishuangbanna BCI Site.pdf

Xianhai, Z. (2012). Improving planting pattern for intercropping in the whole production span of rubber tree. African Journal of Biotechnology, 11(34), 8484-8490.

Yolasiğmaz, H. A., \& Keleş, S. (2009). Changes in carbon storage and oxygen production in forest timber biomass of Balci Forest Management Unit in Turkey between 1984 and 2006. African Journal of Biotechnology, 8(19), 4872-4883.

Yunis, H., Elad, Y., \& Mahrer, Y. (1990). Effects of air temperature, relative humidity and canopy wetness on gray mold of cucumbers in unheated greenhouses. Phytoparasitica, 18(3), 203-215. https://doi.org/10.1007/BF02980990 